\title{
Impaired beta-adrenergic response and decreased L-type calcium current of hypertrophied left ventricular myocytes in postinfarction heart failure
}

\footnotetext{
R.M. Saraiva ${ }^{2}$,

N.G.B. Chedid ${ }^{1}$,

C.C. Quintero H. ${ }^{1}$,

L.E. Díaz G. ${ }^{1}$ and

M.O. Masuda ${ }^{1}$
}

${ }^{1}$ Laboratório de Eletrofisiologia Cardíaca Antonio Paes de Carvalho, Instituto de Biofísica Carlos Chagas Filho, and ${ }^{2}$ Departamento de Cardiologia, Faculdade de Medicina, Universidade Federal do Rio de Janeiro, Rio de Janeiro, RJ, Brasil

\section{Correspondence}

R.M. Saraiva

Rua Abélia, 225/101

Illa do Governador

21940-010 Rio de Janeiro, RJ

Brasil

Fax: +55-21-3393-7683

E-mail: rsaraiva.ntg@terra.com.br

Research supported by CNPq CAPES-MEC, FAPERJ, CEPG-UFRJ and MCT-PRONEX.

Received June 5, 2002 Accepted January 6, 2003

\begin{abstract}
Infarct-induced heart failure is usually associated with cardiac hypertrophy and decreased $\beta$-adrenergic responsiveness. However, conflicting results have been reported concerning the density of L-type calcium current $\left(\mathrm{I}_{\mathrm{Ca}(\mathrm{L})}\right)$, and the mechanisms underlying the decreased $\beta$-adrenergic inotropic response. We determined $\mathrm{I}_{\mathrm{Ca}(\mathrm{L})}$ density, cytoplasmic calcium $\left(\left[\mathrm{Ca}^{2+}\right]_{i}\right)$ transients, and the effects of $\beta$-adrenergic stimulation (isoproterenol) in a model of postinfarction heart failure in rats. Left ventricular myocytes were obtained by enzymatic digestion 8-10 weeks after infarction. Electrophysiological recordings were obtained using the patch-clamp technique. $\left[\mathrm{Ca}^{2+}\right]_{\mathrm{i}}$ transients were investigated via fura-2 fluorescence. $\beta$-Adrenergic receptor density was determined by $\left[{ }^{3} \mathrm{H}\right]$-dihydroalprenolol binding to left ventricle homogenates. Postinfarction myocytes showed a significant $25 \%$ reduction in mean $\mathrm{I}_{\mathrm{Ca}(\mathrm{L})}$ density $(5.7 \pm 0.28 v s .6 \pm 0.32 \mathrm{pA} / \mathrm{pF})$ and a $19 \%$ reduction in mean peak $\left[\mathrm{Ca}^{2+}\right]_{\mathrm{i}}$ transients $(0.13 \pm 0.007$ vs $0.16 \pm$ $0.009)$ compared to sham myocytes. The isoproterenol-stimulated increase in $\mathrm{I}_{\mathrm{Ca}(\mathrm{L})}$ was significantly smaller in postinfarction myocytes ( $\mathrm{E}_{\max }: 63.6 \pm 4.3$ vs $123.3 \pm 0.9 \%$ in sham myocytes), but $\mathrm{EC}_{50}$ was not altered. The isoproterenol-stimulated peak amplitude of $\left[\mathrm{Ca}^{2+}\right]_{\mathrm{i}}$ transients was also blunted in postinfarction myocytes. Adenylate cyclase activation through forskolin produced similar $\mathrm{I}_{\mathrm{Ca}(\mathrm{L})}$ increases in both groups. B-Adrenergic receptor density was significantly reduced in homogenates from infarcted hearts $\left(\mathrm{B}_{\max }: 93.89 \pm 20.22\right.$ vs $271.5 \pm$ $31.43 \mathrm{fmol} / \mathrm{mg}$ protein in sham myocytes), while $\mathrm{Kd}$ values were similar. We conclude that postinfarction myocytes from large infarcts display reduced $\mathrm{I}_{\mathrm{Ca}(\mathrm{L})}$ density and peak $\left[\mathrm{Ca}^{2+}\right]_{\mathrm{i}}$ transients. The response to $\beta$-adrenergic stimulation was also reduced and was probably related to $B$-adrenergic receptor down-regulation and not to changes in adenylate cyclase activity.
\end{abstract}

Key words - $\mathrm{Ca}^{2+}$ channel - Heart failure - Hypertrophy

- Infarction

- Adrenergic receptor 


\section{Introduction}

After myocardial infarction, the acute loss of myocytes leads to an increased load to the heart and to the onset of a cascade of biochemical signaling processes that induce the remodeling of the infarcted zone and of the remote noninfarcted myocardium. Ventricular remodeling is complex and includes hypertrophy, which counterbalances the increased wall stress and attenuates progressive dilation. Nevertheless, heart failure is often the final result of this process after large infarcts $(1,2)$.

The model of chronic infarct in rats is characterized by the presence of hypertrophy and, in the case of large infarcts, of heart failure (3-8), and represents a clinically relevant model of left ventricle dysfunction (9). The decrease in the mechanical performance in this model includes not only the loss of myocardium caused by the infarct, but also decreased contractility and response to $\beta$ adrenergic stimulation of the remaining hypertrophied myocardium $(3,5,8,10)$. However, the mechanisms underlying the reductions of inotropism and the response to Badrenergic stimulation are not completely understood.

The changes in cardiomyocyte function can be traced to several steps in excitationcontraction coupling and calcium handling. Among them, alterations in L-type calcium current $\left(\mathrm{I}_{\mathrm{Ca}(\mathrm{L})}\right)$, cytoplasmic calcium $\left(\left[\mathrm{Ca}^{2+}\right]_{\mathrm{i}}\right)$ transients during contraction, and $\beta$-adrenergic modulation have been studied, but the data in the literature are quite controversial.

L-type calcium currents have been mostly described as unaltered (3,11-14), but also as reduced $(15,16)$ in postinfarction hypertrophied myocytes isolated from the left ventricle (postinfarction myocytes). On the other hand, dihydropyridine (DHP)-binding sites have always been shown to be reduced $(14,17,18)$, even in a study in which $\mathrm{I}_{\mathrm{Ca}(\mathrm{L})}$ density was found to be maintained (14). The peak amplitude of $\left[\mathrm{Ca}^{2+}\right]_{\mathrm{i}}$ transients has been shown to be reduced $(3,11,19)$ or maintained $(5,20)$.

The effect of $\beta$-adrenergic stimulation on the isometric contraction of isolated papillary muscles from infarcted rats has been shown to be reduced $(5,8,21)$. However, the effect of $\beta$-adrenergic stimulation on $\mathrm{I}_{\mathrm{Ca}(\mathrm{L})}$ in postinfarction myocytes has been described either as reduced (14) or maintained (15). Also, the increase in the peak amplitude of $\left[\mathrm{Ca}^{2+}\right]_{\mathrm{i}}$ transients induced by $\beta$-adrenergic stimulation has been shown to be attenuated (5) or augmented (22) in postinfarction myocytes. Binding experiments showed even more diverse results, i.e., maintained (22$25)$, reduced $(6,8,18)$ or increased (26) Badrenergic receptor density.

These conflicting results could reflect the wide variability among the models used by the different investigators. There are important differences in the size of the infarcted area and in the times after infarction that could lead to differences in the severity of hypertrophy and heart failure. In addition, in the case of $\mathrm{I}_{\mathrm{Ca}(\mathrm{L})}$ density, the use of a small number of cells as frequently occurs in electrophysiological experiments may also limit adequate statistical analysis (27) and thus contribute to these controversial results.

Thus, we propose to reevaluate the following parameters in a well-defined model of large chronic infarction in rats, with cellular hypertrophy and clear signals of heart failure, 8 to 10 weeks after surgery: 1 ) $\mathrm{I}_{\mathrm{Ca}(\mathrm{L})}$ density in a large number of cells to permit adequate statistical analysis, 2) $\left[\mathrm{Ca}^{2+}\right]_{\mathrm{i}}$ transients, 3) the effect of $\beta$-adrenergic stimulation on these two parameters, 4) the effect of forskolin (an adenylate cyclase activator) on $\mathrm{I}_{\mathrm{Ca}(\mathrm{L})}$, and 5) the density of $\beta$-adrenergic receptors.

\section{Material and Methods}

\section{Reagents}

The following reagents were used: glucose, $\mathrm{NaCl}, \mathrm{CaCl}_{2}, \mathrm{MgCl}_{2}$ and $\mathrm{KCl}$ (Merck, 
Darmstadt, Germany); 1-isoprenaline hydrochloride, tetraethylammonium chloride (TEA), 4-aminopyridine (4-AP), HEPES, EGTA, Tris, phenylmethylsulfonyl fluoride (PMSF), polyethylenimine, cesium chloride, alprenolol and forskolin (Sigma, St. Louis, MO, USA); collagenase type 2 (Worthington, Lakewood, NJ, USA); EDTA (Reagen, Rio de Janeiro, RJ, Brazil); fura 2-AM (Molecular Probes, Eugene, OR, USA), and $\left[{ }^{3} \mathrm{H}\right]-$ dihydroalprenolol $\left(\left[{ }^{3} \mathrm{H}\right]-\mathrm{DHA}, 120 \mathrm{Ci} / \mathrm{mmol}\right.$; New England Nuclear Life Science Products, Boston, MA, USA).

\section{Experimental infarction}

Myocardial infarction was produced in Wistar rats of both sexes weighing 200-250 $\mathrm{g}$ by ligature of the left coronary artery according to protocols that established the efficacy of the method to produce large infarcts $(16,28)$. Sham-operated rats were subjected to the same surgical procedure, with the exception of left coronary artery ligature. Eight to ten weeks after surgery, age- and sex-matched rats were sacrificed under ether anesthesia and hearts rapidly removed and treated according to the specific experiments to be performed. This investigation conforms to the Guide for the Care and Use of Laboratory Animals published by the US National Institutes of Health (NIH Publication No. 85-23, revised 1996) as attested by the competent institutional board.

\section{Criteria for inclusion in the myocardial infarction group}

Only hearts from infarcted rats that at visual inspection had large infarctions were assigned to the myocardial infarction group. No precise quantification of the infarction was performed since all experiments required a rapid manipulation of the heart soon after animal sacrifice. The efficacy of this visual inspection to include only hypertrophied, failing hearts in this study was confirmed in a group of 13 infarcted and 13 sham-operated animals in which several parameters associated with cardiac hypertrophy and heart failure were evaluated (Table 1).

\section{Cell isolation}

Ventricular myocyte isolation was performed as reported (16). Briefly, after rats were sacrificed, the hearts were rapidly removed and attached to a modified Langendorff apparatus for coronary perfusion with Tyrode solution $(132 \mathrm{mM} \mathrm{NaCl}, 1.25 \mathrm{mM}$ $\mathrm{CaCl}_{2}, 1.2 \mathrm{mM} \mathrm{MgCl}_{2}, 4 \mathrm{mM} \mathrm{KCl}, 10 \mathrm{mM}$ HEPES, and $5 \mathrm{mM}$ glucose, $\mathrm{pH}$ 7.35) saturated with oxygen. When blood was completely washed out the perfusion solution was changed to a calcium-free Tyrode solution until the heart stopped beating. Collagenase $(0.5 \mathrm{mg} / \mathrm{ml})$ was then added and perfusion was maintained until the heart acquired a soft consistency (usually within 6 to $10 \mathrm{~min}$ ). Then, washout of the enzyme was performed by perfusing the heart with the same calcium-free Tyrode solution. Next, fragments of the remaining intact left ventricular free wall and interventricular septum were cut and kept in the calcium-free external solution (142 mM NaCl, $1.0 \mathrm{mM}$ $\mathrm{MgCl}_{2}, 4 \mathrm{mM} \mathrm{KCl}, 10 \mathrm{mM}$ HEPES, and 10 $\mathrm{mM}$ glucose, $\mathrm{pH}$ 7.4), to which $\mathrm{CaCl}_{2}$ was progressively added until the normal concentration of $1.25 \mathrm{mM}$ to prevent cell death by calcium overload. Isolated myocytes were obtained by gently shaking the myocardium fragments in the external solution. Only quiescent rod-shaped cells with smooth borders, sharp striations and no vacuolization were selected for study.

\section{Voltage-clamp studies}

Electrophysiological recordings were performed by the whole-cell technique in voltage-clamp configuration at room temperature $\left(25^{\circ} \mathrm{C}\right)(29)$. The myocytes were kept in an acrylic chamber mounted on the stage of 
an inverted microscope (Nikon DiaphotTMD, Tokyo, Japan) and continuously superfused with the external solution (see composition above) to which $2 \mathrm{mM} 4$-AP had been added.

Cell currents were measured using a patch-clamp amplifier (Axopatch 1D; Axon Instruments, Foster City, CA, USA) and microelectrodes of 4-5 M $\Omega$ tip resistance (when filled with internal solution) made from 1.2$\mathrm{mm}$ outer diameter glass capillaries with a three-stage pipette puller (Sutter Instruments Co., Novato, CA, USA). For data acquisition and analysis, a PC computer connected through a Digidata 1200 interface (Interface Axon Instruments) to the patch-clamp amplifier was used in conjunction with the pCLAMP software version 6.0.3 (Axon Instruments).

The pipette solution contained $100 \mathrm{mM}$ $\mathrm{CsCl}, 20 \mathrm{mM} \mathrm{NaCl}, 0.5 \mathrm{mM} \mathrm{CaCl}_{2}, 2.0 \mathrm{mM}$ $\mathrm{MgCl}_{2}, 11$ mM EGTA-Cs, 10 mM HEPES, and $20 \mathrm{mM}$ TEA-Cl, $\mathrm{pH}$ 7.2. Cesium, 4-AP and TEA were used in order to minimize potassium currents. $\mathrm{I}_{\mathrm{Ca}(\mathrm{L})}$ was elicited by 12 depolarizing clamp steps from a holding potential of $-90 \mathrm{mV}$, with a pre-pulse to $-40 \mathrm{mV}$ for $200 \mathrm{~ms}$ to inactivate $\mathrm{Na}^{+}$and T-type calcium currents (30), and with test potentials ranging from -60 to $+50 \mathrm{mV}$ for $500 \mathrm{~ms}$. The interpulse interval was $4 \mathrm{~s}$ to assure complete recovery from $\mathrm{I}_{\mathrm{Ca}(\mathrm{L})}$ inactivation. $\mathrm{I}_{\mathrm{Ca}(\mathrm{L})}$ was measured as the peak inward current with reference to the current at the end of the test pulse and normalized by dividing the current amplitude by the cell capacitance, measured as previously described (16). Activation curves were plotted as $G_{\text {test }} / G_{\max }$ ratio against voltage. Conductance for each test potential $\left(G_{\text {test }}\right)$ was obtained as previously described (16). The steady-state activation curves were obtained by mathematical adjustment of the data according to Boltzman equation $(\mathrm{y}=\mathrm{A} /\{1 \mathrm{~b}+\exp -[(\mathrm{x}-$ $\left.\left.\mathrm{V}_{0.5}\right) / \mathrm{s}\right]$ \}), where $\mathrm{V}_{0.5}$ is the half-activation potential and $\mathrm{s}$ is the slope factor. Current decay was biphasic and time constants were measured using the following equation: $f(\mathrm{t})=a+b \exp ^{-t / \tau}$ fast $+c \exp ^{-t / \tau}$ slow .

\section{Fluorescence measurements of $\left[\mathrm{Ca}^{2+}\right]_{i}$}

Isolated myocytes placed in a $1.0-\mathrm{ml}$ superfusion chamber mounted on the stage of a Nikon inverted microscope (Diaphot 300) equipped for fluorescence and photometry were loaded with fura 2-AM, the membrane permeant form of an UV-excitable, ratiometric calcium indicator. Fura 2-AM was added to the external solution to a final concentration of $4 \mu \mathrm{M}$ at room temperature and kept for $20 \mathrm{~min}$. The cells were then superfused with the external solution for 5 $\min$ at $0.5 \mathrm{ml} / \mathrm{min}$ to allow complete dye washout. Field stimulation (SEN 3201 stimulator, Nihon Kohden, Tokyo, Japan) was applied at $0.5 \mathrm{~Hz}$ through platinum wire electrodes attached to the bottom and the sides of the chamber. The area for fluorescence measurement was restricted to the minimum necessary to completely include the selected cell in order to minimize background fluorescence. For dye excitation, a high-speed dual-wavelength scanning illuminator (xenon arc lamp, $75 \mathrm{~W}$ ) capable of switching between 340 and $380 \mathrm{~nm}$ at a speed of 650 ratios/s (Delta Scan, Photon Technology International, South Brunswick, NJ, USA) was used. Excitation light was directed at myocytes only during data acquisition to minimize photobleaching. Emitted light was detected by a photomultiplier tube after a 520-nm filter and recorded at 100 points/ s using a computer-based data acquisition system (Photon Technology International). The ratio of the background-subtracted fluorescence signals (340/380) expressed in arbitrary units was used to estimate $\left[\mathrm{Ca}^{2+}\right]_{\mathrm{i}}$.

Peak amplitude, mean rate of increase to the peak (RtPCa) and mean decay rate to $50 \%$ amplitude $\left(\mathrm{RD}_{50}\right)$ of the $\left[\mathrm{Ca}^{2+}\right]_{\mathrm{i}}$ transient elicited by electrical stimulation were measured under control conditions and in the presence of $1 \mu \mathrm{M}$ isoproterenol. Peak 
amplitude of $\left[\mathrm{Ca}^{2+}\right]_{\mathrm{i}}$ transients represents the mean of 10 successive cycles and RtPCa and $\mathrm{RD}_{50}$ were measured in one representative transient for a given experimental condition.

\section{Membrane preparation}

For this purpose, after sacrifice the hearts were rapidly removed and transferred to icecold Tyrode solution. Atria and connective tissue were discarded and the right ventricle, the scar tissue and the remaining left ventricle including the interventricular septum were weighed separately. The scar tissue was discarded and left and right ventricles were processed separately. The following steps were all performed at $4^{\circ} \mathrm{C}$. Ventricular tissue was minced and suspended in ice-cold buffer A (10 mM Tris-HCl, 1 mM EDTA, $0.1 \mathrm{mM}$ PMSF, and $5 \mathrm{mM} \mathrm{MgCl}_{2}, \mathrm{pH} 7.5$ ) and then homogenized with three 15 -s strokes at maximal velocity with a Tissumizer (SDT Tissumizer, Tekmar Company, Cincinnati, $\mathrm{OH}, \mathrm{USA}$ ). Each stroke was separated by a 60 -s resting interval. The suspension was filtered through two layers of cheese-cloth and centrifuged at $4^{\circ} \mathrm{C}$ for $15 \mathrm{~min}$ at 48,000 $g$. The resulting pellet was resuspended in buffer B (similar to buffer A, except for a higher Tris- $\mathrm{HCl}$ concentration of $50 \mathrm{mM}$ ) using a Teflon-glass homogenizer. Next, the suspension was again centrifuged for $30 \mathrm{~min}$ at $48,000 \mathrm{~g}$. This procedure was repeated once again and the final pellet was resuspended and stored at $-70^{\circ} \mathrm{C}$. Protein concentration was determined by the method of Lowry et al. (31) using bovine serum albumin as standard.

\section{Radioligand binding studies}

Left ventricular homogenates of three groups of infarcted and sham-operated animals (total of 20 infarcted and 20 sham animals) were used in the binding experiments. B-Adrenergic receptor density was determined by $\left[{ }^{3} \mathrm{H}\right]$-DHA saturation-bind- ing assays. Fixed quantities of protein (100 $\mu \mathrm{g})$ were incubated in buffer B with increasing concentrations of $\left[{ }^{3} \mathrm{H}\right]$-DHA (5 to 40 $\mathrm{nM})$ at $25^{\circ} \mathrm{C}$ for $1 \mathrm{~h}$. The reaction was stopped by rapid vacuum filtration using a Brandel cell harvester (Semat, Herts, UK) through Whatman GF/B glass fiber filters (Whatman, Madstone, UK) pre-soaked in $0.3 \%$ aqueous polyethylenimine followed by three fast washes with $5 \mathrm{ml}$ ice-cold $10 \mathrm{mM}$ phosphate buffer, $\mathrm{pH}$ 7.4. The filters were dried and the radioactivity trapped in each filter disk was determined by liquid scintillation spectrometry (Packard Instruments Co., Meriden, CT, USA) with a counting efficiency of $45 \%$. Nonspecific binding was defined as the bound radioactivity in the presence of nonlabeled alprenolol $(50 \mu \mathrm{M})$. Specific $\left[{ }^{3} \mathrm{H}\right]$-DHA binding activity was estimated by subtracting the nonspecific binding activity from the total radioligand bound. Estimates of maximal bound $\left(\mathrm{B}_{\max }\right)$ and dissociation constant $(\mathrm{Kd})$ were obtained from least square curve fitting according to the rectangular hyperbolic model (32) using GraphPad Prism 3.02 software (San Diego, CA, USA). All experiments were performed in duplicate.

\section{Statistical analysis}

Data are reported as means \pm SEM. Statistical significance was determined using the unpaired Student $t$-test for the comparison of variables between sham and postinfarction groups. Significance between regression lines was tested by analysis of variance, with $\mathrm{P}<0.05$ being considered statistically significant.

\section{Results}

\section{Experimental model}

According to the inclusion criteria established, the model of myocardial infarction used in this paper corresponds to cardiac hypertrophy and heart failure induced by a 
Table 1. Characteristics of cardiac hypertrophy and heart failure in rats submitted to induction of a large infarct, compared to sham-operated animals.

\begin{tabular}{lrr}
\hline & Sham & Postinfarction \\
\hline Body weight $(\mathrm{g})$ & $252.50 \pm 11.90$ & $252.70 \pm 11.30$ \\
Heart weight $(\mathrm{g})$ & $0.97 \pm 0.05$ & $2.0 \pm 0.08^{*}$ \\
Scar weight $(\mathrm{g})$ & - & $0.23 \pm 0.03$ \\
Organ/body weight ratio (mg/g) & & \\
$\quad$ Heart & $3.89 \pm 0.12$ & $8.05 \pm 0.35^{*}$ \\
Wet lung & $7.35 \pm 0.26$ & $13.34 \pm 0.85^{*}$ \\
$\quad$ Dry lung & $2.50 \pm 0.12$ & $5.84 \pm 0.40^{*}$ \\
$\quad$ Right ventricle & $0.66 \pm 0.04$ & $1.47 \pm 0.09^{*}$ \\
\hline
\end{tabular}

${ }^{*} P<0.001$ compared to sham-operated animals, $N=13$ in each group (unpaired Student $t$-test).

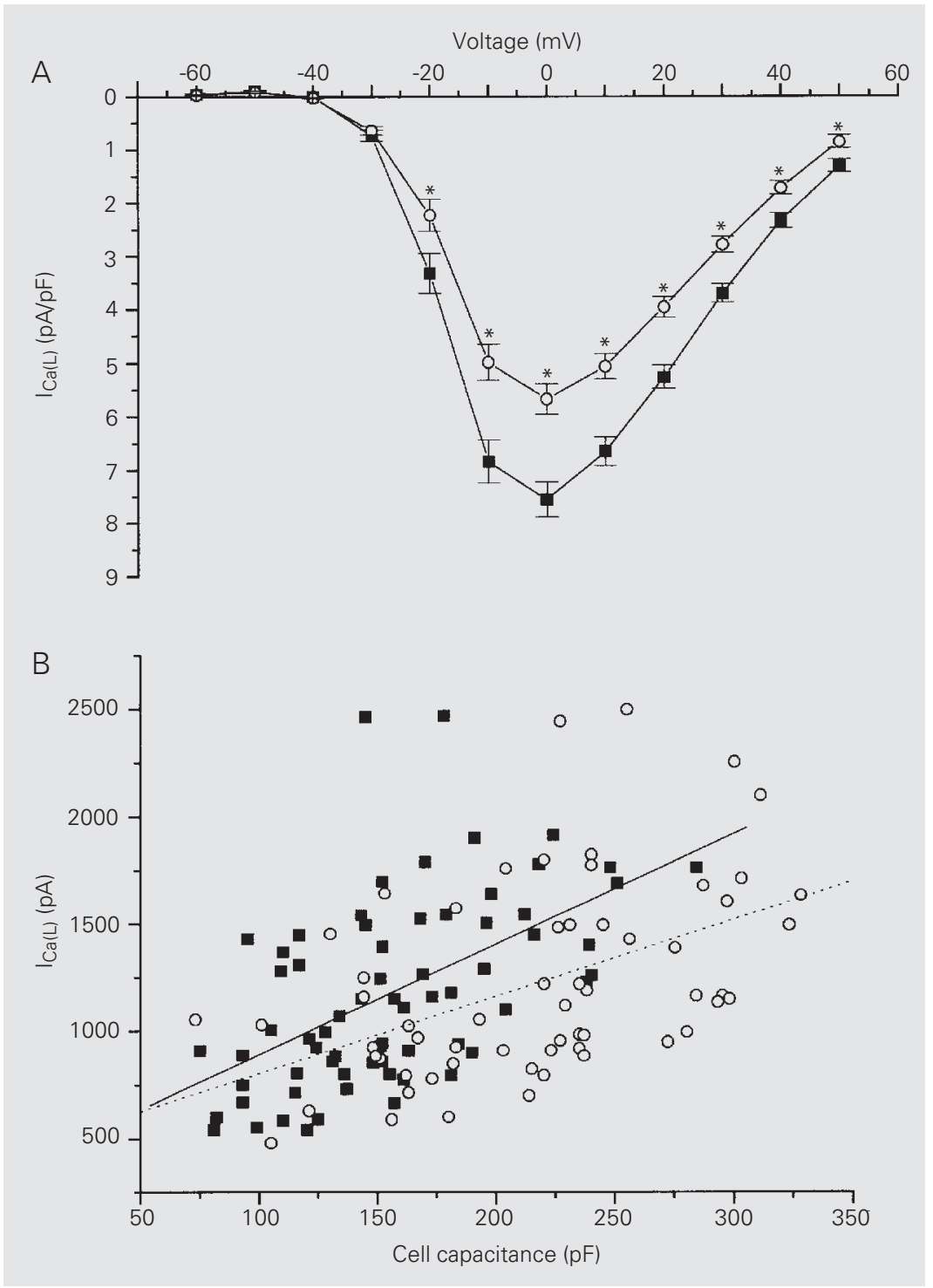

large infarct in rats, 8-10 weeks after surgery. Hypertrophy was quantified in 13 infarcted rats in comparison to 13 sham-operated animals. The presence of hypertrophy in infarcted rats was demonstrated by a significant increase in heart weight (106\%) and heart to body weight ratio (107\%) in postinfarction compared to sham animals (Table 1). Wet and dry lung/body weight ratios were also significantly higher in postinfarction animals (81 and 134\% increases, respectively, Table 1). Right ventricular hypertrophy was also detected: the right ventricle/body weight ratio in postinfarction animals was increased by $123 \%$ compared to sham animals (Table 1). The extent of increase in both wet and dry lung and right ventricle weights observed here corresponds to that reported for large infarcts in rats with reduced ventricular function and increased left ventricular diastolic pressure, which are clear signs of heart failure $(3,4,6,7,10,17,26)$. As expected, we also detected ascites, a typical sign of heart failure in most of the postinfarction animals. The postinfarction myocytes were indeed hypertrophied, with a $38.5 \%$ higher mean capacitance than observed in sham myocytes: $216.4 \pm 7.8 \mathrm{pF}$, $\mathrm{N}=60$, in postinfarction myocytes $v s 156.2$ $\pm 5.5, \mathrm{~N}=69$, in sham myocytes $(\mathrm{P}<0.001)$.

\section{L-type calcium current}

Whole-cell experiments were performed to characterize the $\mathrm{I}_{\mathrm{Ca}(\mathrm{L})}$ density and kinetics.

Figure 1. $A$, L-type calcium current $\left(\mathrm{I}_{\mathrm{Ca}(L)}\right)$ versus voltage plots of sham (squares; $N=69$ ) and postinfarction myocytes (circles; $N=60$ ). Mean peak $I_{C a(L)}$ density is significantly reduced in postinfarction myocytes. ${ }^{*} \mathrm{P}<0.05 \mathrm{com}$ pared to sham (unpaired Student $t$-test). B, Peak $I_{C a(L)}$ versus cell capacitance plots of sham (squares) and postinfarction myocytes (circles). There is a linear relationship between calcium current and cell capacitance in both groups $(r=-0.48, P<0.001$, linear regression, for postinfarction myocytes, $\mathrm{N}=60 ; \mathrm{r}=-0.54, \mathrm{P}<0.001$, linear regression, for sham myocytes, $N=69$ ). Slope values obtained for regression lines did not differ (-3.59 \pm 0.87 for postinfarction myocytes and $-5.15 \pm 0.97$ for sham myocytes, $\mathrm{P}=0.24$ ). 
Mean peak $\mathrm{I}_{\mathrm{Ca}(\mathrm{L})}$ at $0 \mathrm{mV}$ was similar in myocytes from both groups: $1,182 \pm 67 \mathrm{pA}$ $(\mathrm{N}=60)$ for postinfarction myocytes $v s 1,138$ $\pm 51 \mathrm{pA}(\mathrm{N}=69)$ for sham myocytes $(\mathrm{P}=$ $0.59)$. However, after normalization for cell capacitance, mean peak $\mathrm{I}_{\mathrm{Ca}(\mathrm{L})}$ density was $25 \%$ lower in postinfarction myocytes: $5.7 \pm$ 0.28 vs $7.6 \pm 0.32 \mathrm{pA} / \mathrm{pF}$ for sham myocytes $(\mathrm{P}<0.001)$ (Figure 1A).

Comparison of the calcium current densities between the two experimental groups assumes that the relationship between the peak calcium current magnitude and cell capacitance is linear and that this relationship does not change in hypertrophy. To check this point, we plotted the peak calcium current (at $0 \mathrm{mV}$ ) against cell capacitance for each experimental group. As shown in Figure $1 \mathrm{~B}$, we found linear relationships in both groups, and the slope values obtained for the regression lines did not differ significantly. The regression line for postinfarction myocytes was shifted towards lower calcium currents. This point was further corroborated by additional statistical analysis using the extracted residuals from the regression of peak calcium currents. The extracted residuals were used as a new variable in ANOVA and represented variation in peak calcium currents independent of myocyte capacitance. We found that postinfarction myocytes had lower $\mathrm{I}_{\mathrm{Ca}(\mathrm{L})}$ values than those from sham rats when cell size influence was removed from the analysis (ANOVA, $\mathrm{P}<0.05$ ).

In contrast, the calcium current steadystate activation curves were similar for both groups: values for $\mathrm{V}_{0.5}$ were $-15.8 \pm 0.3$ and $-15.2 \pm 0.5 \mathrm{mV}$ for sham $(\mathrm{N}=69)$ and postinfarction $(\mathrm{N}=60)$ myocytes, respectively $(\mathrm{P}=0.27)$. Slope factors were $5.3 \pm 0.3$ and $5.5 \pm 0.4 \mathrm{mV}$ for sham and postinfarction myocytes, respectively $(\mathrm{P}=0.69)$. The time course of $\mathrm{I}_{\mathrm{Ca}(\mathrm{L})}$ inactivation was biphasic. Fast $\left(\tau_{\text {fast }}\right)$ and slow $\left(\tau_{\text {slow }}\right)$ time constants were determined at maximal current density, measured at $0 \mathrm{mV}$, and also did not differ significantly. $\tau_{\text {fast }}$ was $24.0 \pm 1.2$ and $26.1 \pm$ $1.4 \mathrm{~ms}$, for sham $(\mathrm{N}=57)$ and postinfarction $(\mathrm{N}=49)$ myocytes, respectively $(\mathrm{P}=0.25)$, and $\tau_{\text {slow }}$ was $134.8 \pm 11.7$ and $134.8 \pm 12.4$ $\mathrm{ms}$, for sham and postinfarction myocytes, respectively $(\mathrm{P}=0.99)$.

\section{$\mathbf{I}_{\mathrm{Ca}(\mathrm{L})} ß$-adrenergic sensitivity}

In order to evaluate the $\mathrm{I}_{\mathrm{Ca}(\mathrm{L})}$ response to B-adrenergic stimulation we exposed the cells to different concentrations of isoproterenol. A given cell was exposed to only one isoproterenol concentration. Therefore, each concentration value was tested in a different group of cells. The $\mathrm{I}_{\mathrm{Ca}(\mathrm{L})}$ increase induced by isoproterenol was less prominent in postinfarction myocytes, as shown in Figure 2 (inset). Dose-response curves for isoproterenol were constructed with the average

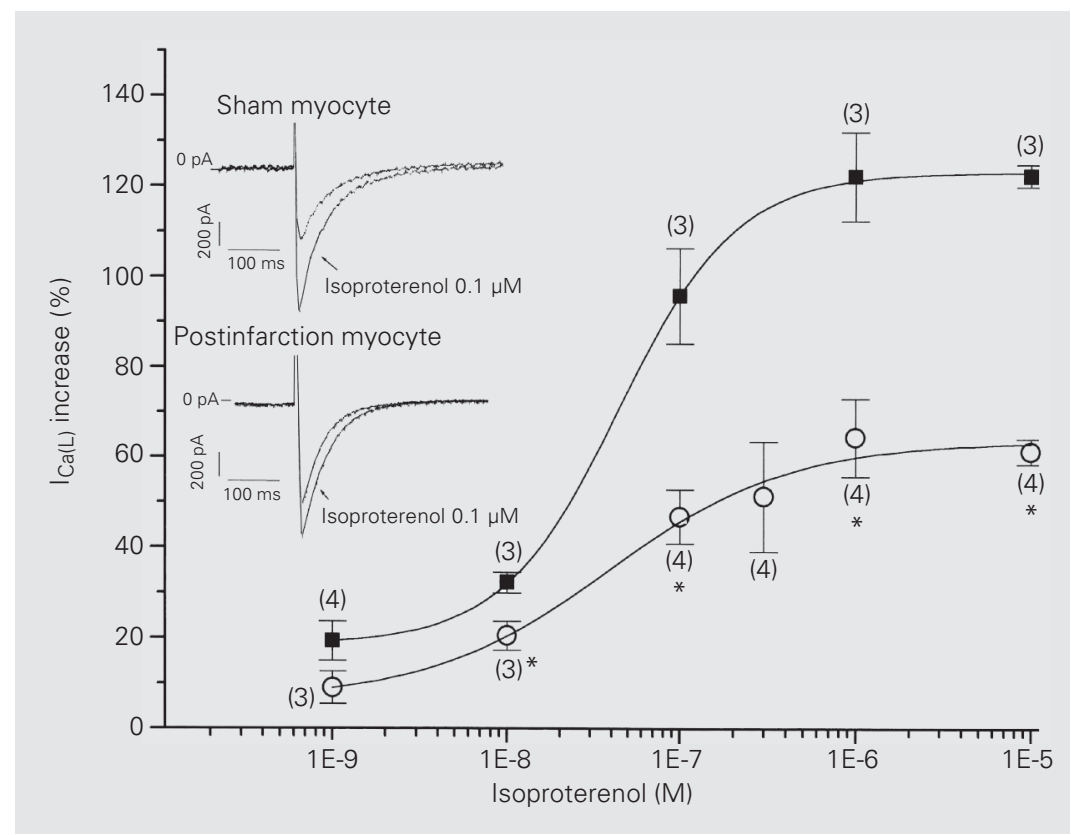

Figure 2. Dose-response curves for isoproterenol on L-type calcium current $\left(\mathrm{I}_{\mathrm{Ca}(\mathrm{L})}\right)$. Note the smaller increase of $\mathrm{I}_{\mathrm{Ca}(L)}$ density in postinfarction (circles) than in sham myocytes (squares): $E_{\max }$ was $63.6 \pm 4.3 \%$ in postinfarction and $123.3 \pm 0.9 \%$ in sham myocytes, $P<0.001$. The $\mathrm{EC}_{50}$ was similar for both groups: $38 \pm 20 \mathrm{nM}$ in postinfarction and $44 \pm 2 \mathrm{nM}$ in sham myocytes ( $P>0.5$, sigmoidal curve fit using logistical equation). ( $N$ ), tested cell number for each point; ${ }^{*} \mathrm{P}<0.05$ (unpaired Student $t$-test). Inset shows $\mathrm{I}_{\mathrm{Ca}(\mathrm{L})}$ records in sham and postinfarction myocytes. I $\mathrm{C}_{(\mathrm{L}}(\mathrm{L})$ was recorded in whole-cell voltage clamp mode before and during exposure to $0.1 \mu \mathrm{M}$ isoproterenol in the same myocyte. Test voltage was $0 \mathrm{mV}$ for all data. 
maximal $\mathrm{I}_{\mathrm{Ca}(\mathrm{L})}$ density increases obtained for each concentration. After sigmoidal fit, a clear reduction in the effect of $B$-adrenergic stimulation on $\mathrm{I}_{\mathrm{Ca}(\mathrm{L})}$ could be seen in postinfarction myocytes (Figure 2). The maximum effect $\left(\mathrm{E}_{\max }\right)$ was reduced by $48 \%$ in postinfarction versus sham myocytes. Isoproterenol potency was similar for both groups of

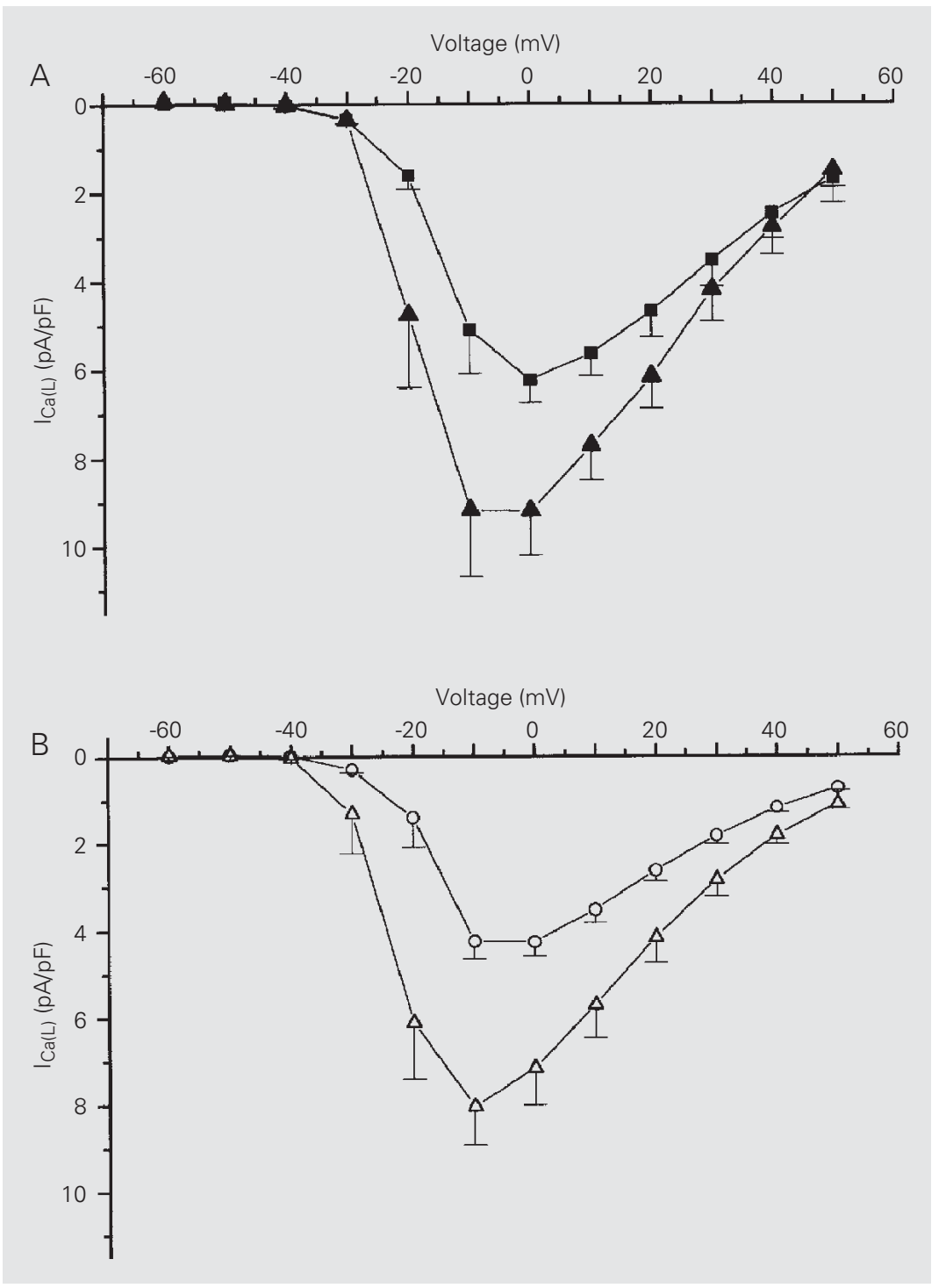

Figure 3. Effect of forskolin on L-type calcium current $\left(\mathrm{I}_{\mathrm{Ca}(\mathrm{L})}\right)$. Forskolin $(10 \mu \mathrm{M})$ added to the extracellular saline provoked similar increases in $\mathrm{I}_{\mathrm{Ca}(L)}$ density in both sham $(A$, filled squares in the absence and filled triangles in the presence of forskolin) and postinfarction myocytes ( $B$, open circles in the absence and open triangles in the presence of forskolin). There was no significant difference in the mean increase of $\mathrm{I}_{\mathrm{Ca}(\mathrm{L})}$ induced by forskolin at any voltage in both groups. At $-10 \mathrm{mV}$ test voltage, the increases were $90.0 \pm 12.9 \%(\mathrm{~N}=4)$ in postinfarction and $91.2 \pm 27.2 \%(N=5)$ in sham myocytes $(P=0.9$, unpaired Student $t$-test). cells, as demonstrated by similar dose for $50 \%$ of maximum effect $\left(\mathrm{EC}_{50}\right)$ found in both groups of cells (Figure 2).

\section{Effect of forskolin on $\mathrm{I}_{\mathrm{Ca}(\mathrm{L})}$ density}

To investigate the effect of hypertrophy on adenylate cyclase activity, forskolin, a direct activator of adenylate cyclase, was applied to the external solution. Forskolin induced similar increases in $\mathrm{I}_{\mathrm{Ca}(\mathrm{L})}$ in both groups (Figure 3), suggesting that the $\beta$-adrenergic pathway downstream of the adenylate cyclase step is preserved in postinfarction myocytes.

\section{$\left[\mathrm{Ca}^{2+}\right]_{i}$ transients and the effect of isoproterenol}

The mean resting $\left[\mathrm{Ca}^{2+}\right]_{\mathrm{i}}$ was $0.40 \pm 0.01$ (arbitrary units) for both postinfarction $(\mathrm{N}=$ $34)$ and sham $(\mathrm{N}=33)$ myocytes. The mean peak amplitude of $\left[\mathrm{Ca}^{2+}\right]_{\mathrm{i}}$ transients (Figure 4A) and RtPCa (Figure 4B) upon stimulation at $0.5 \mathrm{~Hz}$ were significantly lower in postinfarction myocytes. There was no difference in $\mathrm{RD}_{50}$ between the two groups (Figure 4B). Figure 4F, left (control), shows records of fluorescence ratios (340/380) versus time obtained from representative postinfarction and sham myocytes. Thus, upon stimulation at 0.5 $\mathrm{Hz}$, the $\left[\mathrm{Ca}^{2+}\right]_{\mathrm{i}}$ transient increased more slowly and to lower values in postinfarction myocytes compared to sham myocytes.

Figure $4 \mathrm{C}, \mathrm{D}$ and $\mathrm{E}$ show that $1 \mu \mathrm{M}$ isoproterenol significantly increased all three parameters, mean peak amplitude of $\left[\mathrm{Ca}^{2+}\right]_{\mathrm{i}}$ transients, RtPCa, and $\mathrm{RD}_{50}$, both in postinfarction and sham myocytes.

Figure $4 \mathrm{C}$ also shows that the mean peak amplitude of the $\left[\mathrm{Ca}^{2+}\right]_{i}$ transient in the presence of isoproterenol $(1 \mu \mathrm{M})$ was lower in postinfarction than in sham myocytes. However, the relative increases of the mean peak amplitudes of $\left[\mathrm{Ca}^{2+}\right]_{\mathrm{i}}$ transients induced by isoproterenol were not significantly different between the two groups: $76.5 \pm 11.0 \%$ $(\mathrm{N}=8)$ in postinfarction and $86.8 \pm 10.5 \%$ 


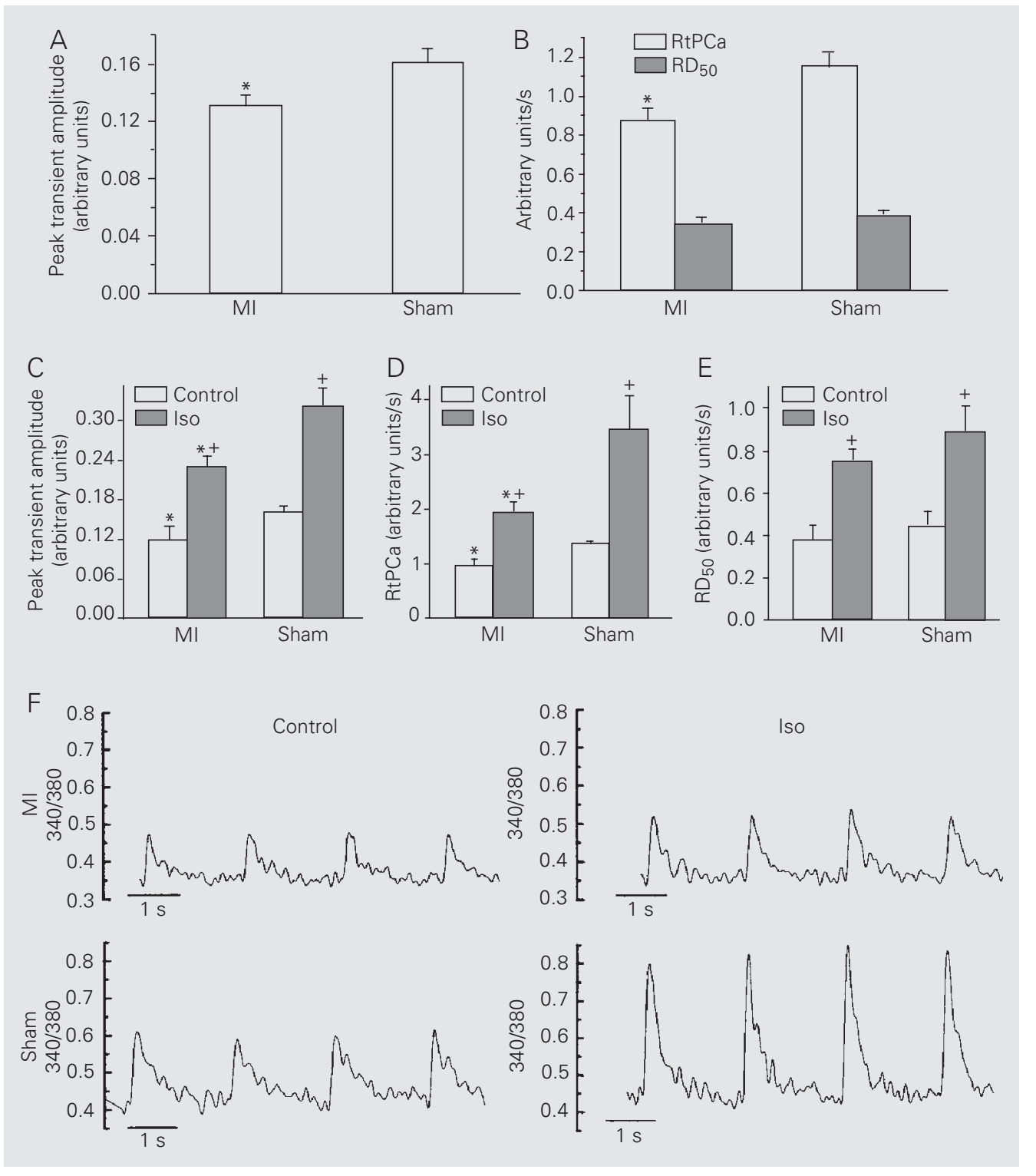

Figure 4. Cytoplasmic calcium $\left(\left[\mathrm{Ca}^{2+}\right]_{\mathrm{i}}\right)$ transient parameters obtained from isolated ventricular myocytes loaded with fura 2-AM. A, Peak amplitudes of $\left[\mathrm{Ca}^{2+}\right]_{i}$ transients measured from the resting level: $0.13 \pm 0.007, \mathrm{~N}=34$, in postinfarction (MI) and $0.16 \pm 0.009, N=33$, in sham myocytes ( $P=0.01$, unpaired Student $t$-test). $B$, Rates of increase to peak (RtPCa), and of decay to $50 \%$ amplitude $\left(\mathrm{RD}_{50}\right)$ of the $\left[\mathrm{Ca}^{2+}\right]_{i}$ transients: RtPCa: $0.87 \pm 0.0067$, $\mathrm{N}=34$, in $\mathrm{Ml}$ and $1.15 \pm 0.075$ units/s, $\mathrm{N}=33$, in sham $(\mathrm{P}<0.001)$ and $\mathrm{RD}_{50}: 0.34 \pm 0.028, \mathrm{~N}=34$, in $\mathrm{Ml}$ and 0.38 \pm 0.022 units $/ \mathrm{s}, \mathrm{N}=33$, in sham myocytes $(\mathrm{P}=0.27$, unpaired Student $t$-test). $C$, Peak transient amplitudes, $D, R t P C a$, and $E, R_{50}$ of the $\left[\mathrm{Ca}^{2+}\right]_{i}$ transients under control condition and in the presence of $1 \mu \mathrm{M}$ isoproterenol in $\mathrm{Ml}$ and sham myocytes. Isoproterenol induced an increase in peak amplitudes of the $\left[\mathrm{Ca}^{2+}\right]_{i}$ transients from $0.12 \pm$ 0.02 to $0.23 \pm 0.01, \mathrm{~N}=8$, in $\mathrm{Ml}$ and from $0.16 \pm 0.01$ to $0.32 \pm 0.04, \mathrm{~N}=7$, in sham. RtPCa was increased in $\mathrm{MI}$ from $0.97 \pm 0.13$ to $1.94 \pm 0.18$ units/s, $N=8$, and in sham from $1.36 \pm 0.40$ to $3.43 \pm 0.63$ units/s, $N=7$; isoproterenol-induced increase in $\mathrm{RD}_{50}$ was from $0.38 \pm 0.07$ to $0.75 \pm 0.09$ units/s, $\mathrm{N}=8$, in $\mathrm{Ml}$ and from $0.45 \pm$ 0.07 to $0.89 \pm 0.13$ units $/ \mathrm{s}, \mathrm{N}=7$, in sham. Measurements of $\left[\mathrm{Ca}^{2+}\right]_{i}$ transients were always performed first under control condition and then in the presence of the drug in the same cell. Each cell was exposed only once to isoproterenol to avoid desensitization. F, Sample records from one MI and one sham cell, bathed in control saline (control) and at 3rd minute of exposure to $1 \mu \mathrm{M}$ isoproterenol. ${ }^{*} \mathrm{P}<0.05$ for comparisons between $\mathrm{Ml}$ and sham, and $+\mathrm{P}<0.05$ for comparisons between isoproterenol and control (unpaired Student $t$-test). Iso, isoproterenol. 
$(\mathrm{N}=7)$ in sham myocytes $(\mathrm{P}=0.52)$. The relative increases in RtPCa and $\mathrm{RD}_{50}$ induced by isoproterenol were also similar in both groups: $109.0 \pm 24.4 \%$ in postinfarction and $137.8 \pm 26.5 \%$ in sham myocytes (RtPCa), $\mathrm{P}=0.48$, and $89.0 \pm 30.4 \%$ in postinfarction and $91.7 \pm 16.0 \%$ in sham myocytes $\left(\mathrm{RD}_{50}\right), \mathrm{P}=0.94$. Figure $4 \mathrm{~F}$ shows the effect of $1 \mu \mathrm{M}$ isoproterenol on representative postinfarction and sham myocytes.

\section{ß-Adrenergic receptor density}

The $\left[{ }^{3} \mathrm{H}\right]$-DHA binding was significantly lower in homogenates of left ventricles of myocardial infarction hearts as shown by the saturation curves in Figure 5. The calculated $\mathrm{B}_{\max }$ of $\left[{ }^{3} \mathrm{H}\right]$-DHA for myocardial infarction corresponded to $35 \%$ of the value found for sham myocytes, indicating that the maximal number of radioligand binding sites was decreased in myocardial infarction hearts. Scatchard analysis of the data (Figure 5, inset)

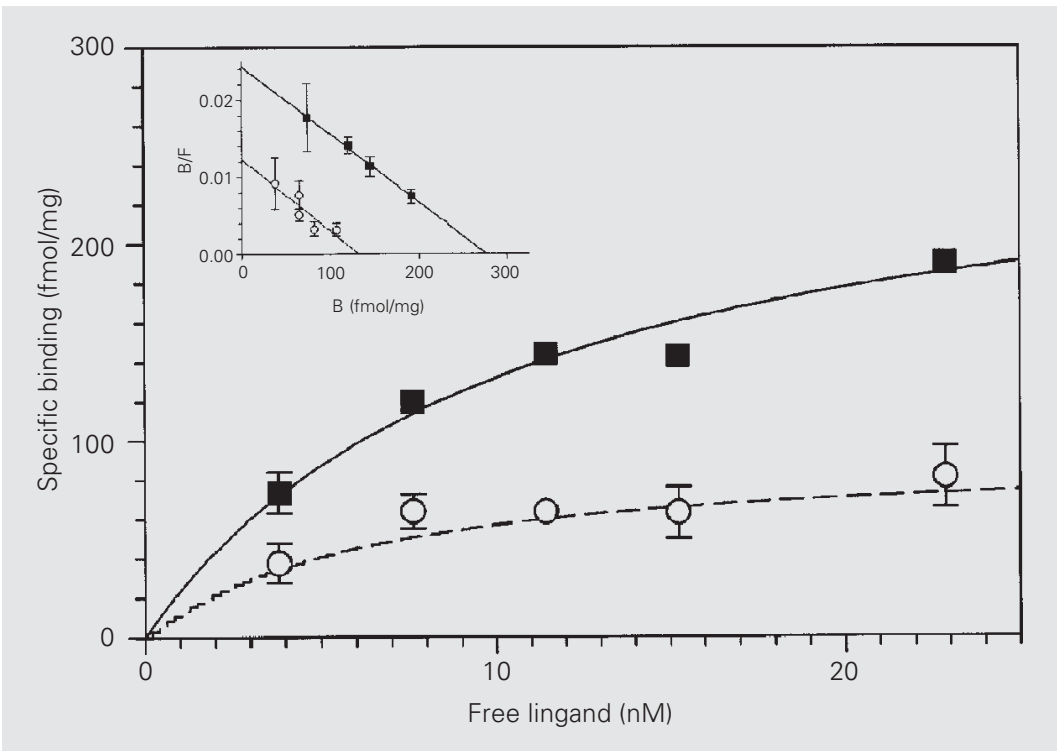

Figure 5. Saturation binding isotherm of $\left[{ }^{3} \mathrm{H}\right]-\mathrm{DHA}$ binding to left ventricle homogenates in sham (squares) and myocardial infarction (MI) rat heart (circles). Inset shows Scatchard analysis of the data. $B_{\max }$ was $93.89 \pm 20.22$ in $\mathrm{Ml}$ and $271.5 \pm 31.43 \mathrm{fmol} / \mathrm{mg}$ protein in sham, $\mathrm{P}=0.009$, nonlinear regression according to rectangular hyperbolic model, $\mathrm{N}=3$. No significant difference in $\mathrm{Kd}$ values was observed between the groups: $10.69 \pm 3.78$ for $\mathrm{Ml}$ and $11.37 \pm 3.68 \mathrm{nM}$ for sham hearts. The average values were obtained in three duplicate experiments. indicated that the equilibrium dissociation constants were the same for both membrane preparations, suggesting a noninteracting single population of DHA binding sites in both postinfarction and sham myocytes.

\section{Discussion}

This is the first study in which calcium current densities, intracellular calcium transients and binding to $\beta$-adrenergic receptors were evaluated simultaneously in a welldefined model of cardiac hypertrophy. We were able to show decreased cardiac $B$-adrenergic response, impairment of $\mathrm{I}_{\mathrm{Ca}(\mathrm{L})}$ under basal or stimulated conditions, and decreased $\left[\mathrm{Ca}^{2+}\right]_{\mathrm{i}}$ transients upon stimulation in the model of hypertrophied failing heart, 8-10 weeks after extensive myocardial infarction.

\section{L-type calcium channel}

The linear correlation between peak $\mathrm{I}_{\mathrm{Ca}(\mathrm{L})}$ and cell capacitance for both postinfarction and sham myocytes with almost parallel regression lines validates the procedure of comparing current densities normalized by cell capacitance in this model. The analysis of the extracted residuals from the regression of peak calcium currents showed that the decrease in peak calcium current in myocardial infarction is independent of cell size.

In contrast to most studies, in which $\mathrm{I}_{\mathrm{Ca}(\mathrm{L})}$ density is evaluated in a small number of cells, in the present investigation, by analyzing a larger number of cells, we confirmed that $\mathrm{I}_{\mathrm{Ca}(\mathrm{L})}$ density is indeed reduced (Figure 1A) in postinfarction myocytes, in agreement with the reduction in DHP binding sites described in homogenates from infarcted rats $(14,17,18)$.

In contrast, several investigators reported preservation of $\mathrm{I}_{\mathrm{Ca}(\mathrm{L})}$ density in postinfarction myocytes (3,11-14). What could underly this discrepancy? In some cases, the degree of hypertrophy is clearly different: the increase in mean capacitance of myocardial infarction cells in the present study (38.5\%) 
was larger than the $11 \%(3)$ and $12 \%(14)$ values reported by others. The smaller hypertrophy inferred from the capacitance measurements in the study by Holt et al. (3) was confirmed by the smaller increase in the heart weight/body weight ratio in myocardial infarction, which was $67 \%$ in comparison to the $107 \%$ increase found in our model. Thus, the degree of cardiac hypertrophy possibly related to the intensity of left ventricular overload could be one variable associated with the decreased $\mathrm{I}_{\mathrm{Ca}(\mathrm{L})}$ density in postinfarction myocytes. Additionally, Qin et al. (12), Holt et al. (3) and Wasserstrom et al. (13), who did not find alterations in peak $\mathrm{I}_{\mathrm{Ca}(\mathrm{L})}$ density, were all working with myocardial infarction rats earlier after experimental infarction, i.e., 3-4 weeks (12) and 6 weeks $(3,13)$, when compared to the present model. Thus, time elapsed after myocardial infarction, which determines the degree of progression of heart failure, could be another important parameter. Accordingly, Aimond et al. (15) reported decreased $\mathrm{I}_{\mathrm{Ca}(\mathrm{L})}$ density (by $45 \%$ ) in postinfarction myocytes $4-6$ months after infarction in a model with clear signs of left ventricular dysfunction evaluated by echocardiography and hemodynamic parameters.

\section{Calcium transients}

In the present study, mean peak amplitudes of $\left[\mathrm{Ca}^{2+}\right]_{\mathrm{i}}$ transients and RtPCa (a parameter that estimates the velocity of calcium release) were reduced in postinfarction myocytes, in agreement with a report by Holt et al. (3), who also reported decreased fractional shortening and increased times to peak tension and recovery. Anand et al. (33), on the other hand, reported unchanged $\left[\mathrm{Ca}^{2+}\right]_{\mathrm{i}}$ transients in a model with signs of heart failure. However, in this case the degree of left ventricular impairment was clearly less severe, a fact that may explain the different results.

Our observations of decreased $\mathrm{I}_{\mathrm{Ca}(\mathrm{L})}$ and peak calcium transient conform with previ- ous reports of a linear relation between the magnitudes of $\mathrm{I}_{\mathrm{Ca}(\mathrm{L})}$ and of $\mathrm{Ca}^{2+}$ release, and with the proposals that reductions of at least $20 \%$ in $\mathrm{I}_{\mathrm{Ca}(\mathrm{L})}$ density can disturb intracellular calcium handling (27).

Thus, in our model the decreased contractility reported for the whole heart and papillary muscle $(6,8)$ may be associated with the reduced trigger represented by the reduced $\mathrm{I}_{\mathrm{Ca}(\mathrm{L})}$ density (Figure 1A), leading to decreased calcium mobilization during systole. However, we cannot rule out a contribution of other mechanisms to the reduction of the peak amplitude of $\left[\mathrm{Ca}^{2+}\right]_{i}$ transients, such as a smaller calcium store in sarcoplasmic reticulum (34) and a decrease in the ability of $\mathrm{I}_{\mathrm{Ca}(\mathrm{L})}$ to activate sarcoplasmic reticulum $\mathrm{Ca}^{2+}$ release (11).

On the other hand, $\mathrm{RD}_{50}$, which estimates the rate of decay of the $\left[\mathrm{Ca}^{2+}\right]_{\mathrm{i}}$ transient following a contraction, was found to be unaltered in postinfarction myocytes, as also shown by Prahash et al. (22), possibly indicating that the mechanisms of calcium clearance are preserved or that these cells develop some kind of compensatory mechanism.

\section{Depressed $\beta$-adrenergic response in postinfarction myocytes}

Heart failure syndrome is accompanied by compensating mechanisms and one of the most important is increased adrenergic drive. It has been suggested in other hypertrophy models that the beginning of the hypertrophic process is associated with increased or maintained $B$-adrenergic response and receptor density; and, as heart failure is established, $\beta$-adrenergic receptor density decreases (35). The $\beta$-adrenergic response is also modified in infarct-induced hypertrophy. Although most of the literature reports a reduction in $\beta$-adrenergic response of isolated hearts or hypertrophied papillary muscles of infarcted hearts $(5,6,8,21,22)$, no clear agreement exists regarding the step(s) in the signaling pathway responsible for this reduction. 
We found a significant decrease in the $\mathrm{E}_{\max }$ of isoproterenol on $\mathrm{I}_{\mathrm{Ca}(\mathrm{L})}$ in postinfarction myocytes compared to sham myocytes, while the $\mathrm{EC}_{50}$ was unchanged. The $\mathrm{E}_{\max }$ of isoproterenol obtained for sham myocytes was similar to values previously reported for adult rat hearts (36), while the present study is the first report of $\mathrm{E}_{\max }$ and $\mathrm{EC}_{50}$ in postinfarction rat myocytes. The maintenance of $\mathrm{EC}_{50}$ and the decrease in $\mathrm{E}_{\max }$ in postinfarction myocytes suggest that the reduced effect of isoproterenol on these cells is more likely to be related to a decreased $\beta$-adrenergic receptor density rather than to a change in affinity of the $ß$-adrenergic receptor. Furthermore, the isoproterenol-stimulated mean peak amplitude of the $\left[\mathrm{Ca}^{2+}\right]_{i}$ transients was lower in postinfarction myocytes (Figure 4) although the relative increases induced by 1 $\mu \mathrm{M}$ isoproterenol were the same for sham and myocardial infarction rats.

The functional evidence cited above for decreased $ß$-adrenergic receptor density with maintained affinity of the receptor for the agonist is in good agreement with the significant reduction in the calculated $\mathrm{B}_{\max }$ of $\left[{ }^{3} \mathrm{H}\right]$ DHA binding to the postinfarction left ventricular tissue preparation (Figure 5), without changes in $\mathrm{Kd}$. Taking into account the increase in right ventricle/body weight (123\%) and in wet lung/body weight (81\%) ratios in the present study, the magnitudes of hypertrophy and heart failure in our model were higher than in studies that reported preservation of $\beta$ adrenergic receptor density $(4,23)$, and similar to studies that also reported a decrease in $\beta$ adrenergic receptor density $(6,8)$. Thus, whether or not $\beta$-adrenergic receptor density is decreased in a given model of myocardial infarction seems to depend also on the severity of heart failure.

This decreased $B$-adrenergic receptor density could be an additional cause for the decreased basal $\mathrm{I}_{\mathrm{Ca}(\mathrm{L})}$ density in this model since it is proposed that $\mathrm{G}$ protein-coupled receptors, including $\beta$-adrenergic receptor, exert a basal amount of intrinsic activity leading to basal steady-state adenylate cyclase activity (37).

The possibility that the reduction shown in the present study could be related to decreased $\beta$-adrenergic receptor density limited to the scar and neighboring tissue $(4,24)$ is not likely since we removed the scars before homogenization of the left ventricles.

Forskolin stimulation induced similar effects on $\mathrm{I}_{\mathrm{Ca}(\mathrm{L})}$ density in sham and postinfarction myocytes, in agreement with previous studies that evaluated chronotropic and inotropic responses to forskolin $(4,22)$. This finding, taken together with the decreased $ß$-adrenergic receptor density, limits the possible altered steps in the $\beta$-adrenergic pathway in postinfarction myocytes to the receptor-G protein complex and suggests the interpretation that the decrease in $ß$-adrenergic receptor density is a possible mechanism underlying the reduced $B$-adrenergic stimulation response in postinfarction myocardium.

We propose that in the cardiac hypertrophy model induced by large infarcts in rats with clear signs of heart failure, evaluated 810 weeks after infarction, $\mathrm{I}_{\mathrm{Ca}(\mathrm{L})}$ density and mean peak amplitude of $\left[\mathrm{Ca}^{2+}\right]_{i}$ transients are both reduced, events that may contribute to the decreased contractility of postinfarction myocardium. The decrease of the response of $\mathrm{I}_{\mathrm{Ca}(\mathrm{L})}$ to ß-adrenergic stimulation in postinfarction myocardium is not related to changes in adenylate cyclase function or sensitivity of $\beta$-adrenergic receptors to the agonist, with down-regulation of $\beta$-adrenergic receptors being an important mechanism. The controversial reports concerning $\mathrm{I}_{\mathrm{Ca}(\mathrm{L})}$ density and $\beta$-adrenergic effects on hypertrophied myocytes in healed infarction are probably related to differences in the severity of heart failure in different studies.

\section{Acknowledgments}

We are indebted to Dr. Antonio Carlos Campos de Carvalho for a critical review of the manuscript. 


\section{References}

1. Sutton MGJ \& Sharpe N (2000). Left ventricular remodeling after myocardial infarction. Pathophysiology and therapy. Circulation, 101: 2981-2988.

2. Swynghedauw B (1999). Molecular mechanisms of myocardial remodelling. Physiological Reviews, 79: 215-262.

3. Holt E, Tonnessen T, Lunde PK, Semb SO, Wasserstrom JÁ, Sejersted OM \& Christensen G (1998). Mechanism of cardiomyocyte dysfunction in heart failure following myocardial infarction in rats. Journal of Molecular and Cellular Cardiology, 30: 1581-1593.

4. Kompa AR, Gu X-H, Evans BA \& Summers RJ (1999). Desensitization of cardiac $\beta$-adrenoceptor signaling with heart failure produced by myocardial infarction in the rat. Evidence for the role of Gi but not Gs or phosphorylating proteins. Journal of Molecular and Cellular Cardiology, 31: 1185-1201.

5. Litwin SE \& Morgan JP (1992). Captopril enhances intracellular calcium handling and ß-adrenergic responsiveness of myocardium from rats with postinfarction failure. Circulation Research, 78: 797807.

6. Sanbe A \& Takeo S (1995). Diminished responsiveness to cardiac $\beta_{1}$-adrenoceptor agonists in rats with chronic heart failure following myocardial infarction. Biological and Pharmaceutical Bulletin, 18: 1362-1366.

7. Sethi R, Dhalla KS, Beasmish RE \& Dhalla NS (1997). Differential changes in left and right ventricular adenyl cyclase activities in congestive heart failure. American Journal of Physiology, 272: H884H893.

8. Warner AL, Bellah KL, Raya TE, Roeske WR \& Goldman S (1992). Effects of $ß$-adrenergic blockade on papillary muscle function and the $ß$-adrenergic receptor system in noninfarcted myocardium in compensated ischemic left ventricular dysfunction. Circulation, 86: 1584-1595.

9. Hasenfuss G (1998). Animal models of human cardiovascular disease, heart failure and hypertrophy. Cardiovascular Research, 39: 60-76.

10. Mill JG, Novaes MAS, Galon M, Nogueira JB \& Vassallo DV (1998). Comparison of the contractile performance of the hypertrophied myocardium from spontaneous hypertensive rats and normotensive infarcted rats. Canadian Journal of Physiology and Pharmacology, 76: 387-394.

11. Gómez AM, Guatimosim S, Dilly KW, Vassort G \& Lederer WJ (2001). Heart failure after myocardial infarction. Altered excitationcontraction coupling. Circulation, 104: 688-693.

12. Qin D, Zhang Z, Caref EB, Boutjdir M, Jain P \& El-Sherif N (1996). Cellular and ionic basis of arrhythmias in postinfarction remodeled ventricular myocardium. Circulation Research, 79: 461-473.

13. Wasserstrom JÁ, Holt E, Sjaastad I, Lunde PK, Ødegaard A \& Sejersted OM (2000). Altered E-C coupling in rat ventricular myocytes from failing hearts $6 \mathrm{wk}$ after MI. American Journal of Physiology, 279: H798-H807.

14. Zhang XQ, Moore RL, Tillotson DL \& Cheung JY (1995). Calcium currents in postinfarction rat cardiac myocytes. American Journal of Physiology, 269: C1464-C1473.

15. Aimond F, Alvarez JL, Rauzier J-M, Loronte P \& Vassort G (1999). Ionic basis of ventricular arrhythmias in remodeled rat heart during long-term myocardial infarction. Cardiovascular Research, 42: 402415.

16. Santos PEB, Barcellos LC, Mill JG \& Masuda MO (1995). Ventricular action potential and L-type calcium channel in infarct-induced hypertrophy in rats. Journal of Cardiovascular Electrophysiology, 6: 1004-
1014.

17. Dixon IMC, Lee SL \& Dhalla NS (1990). Nitrendipine binding in congestive heart failure due to myocardial infarction. Circulation Research, 66: 782-788.

18. Gopalakrishnan M, Triggle DJ, Rutledge A, Kwon YW, Bauer JÁ \& Fung $\mathrm{H}-\mathrm{L}$ (1991). Regulation of $\mathrm{K}^{+}$and $\mathrm{Ca}^{2+}$ channels in experimental cardiac failure. American Journal of Physiology, 261: H1979H1987.

19. Zhang XQ, Moore RL, Tenhave $T$ \& Cheung JY (1995). [Ca $\left.{ }^{2+}\right]_{i}$ transients in hypertensive and postinfarction myocytes. American Journal of Physiology, 269: C632-C640.

20. Tajima M, Weinberg EO, Bartunek J, Jin H, Yang R, Paoni NF \& Lorell BH (1999). Treatment with growth hormone enhances contractile reserve and intracellular calcium transients in myocytes from rats with postinfarction heart failure. Circulation, 99: 127-134.

21. Oi X \& Rouleau JL (1996). Beta-adrenergic responsiveness of papillary muscles in the rat postinfarction model. Canadian Journal of Physiology and Pharmacology, 74: 1166-1170.

22. Prahash AJ, Gupta S \& Anand IS (2000). Myocyte response to betaadrenergic stimulation is preserved in the noninfarcted myocardium of globally dysfunctional rat hearts after myocardial infarction. Circulation, 102: 1840-1846.

23. Chasteney EA, Liang C-S \& Hood WB (1992). Beta-adrenoceptor and adenylate cyclase function in the infarct model of rat heart failure. Proceedings of the Society for Experimental Biology and Medicine, 200: 90-94.

24. van Veldhuisen DJ, Brode OE, van Gilst WH, Schulze C, Hegeman H, Anthonio RL, Scholtens E, Graeff PA, Wesseling H \& Lie KI (1995). Relation between myocardial ß-adrenoceptor density and hemodynamic and neurohumoral changes in a rat model of chronic myocardial infarction: effects of ibopamine and captopril. Cardiovascular Research, 30: 386-393.

25. Yamamoto J, Ohyanagi M, Morita M \& Iwasaki T (1994). ß-Adrenoceptor-G protein-adenylate cyclase complex in rat hearts with ischemic heart failure produced by coronary artery ligation. Journal of Molecular and Cellular Cardiology, 26: 617-626.

26. Clozel JP, Holck M, Osterrieder W, Burkard W \& Prada M (1987). Effects of chronic myocardial infarction on responsiveness to isoprenaline and the state of myocardial beta adrenoceptors in rats. Cardiovascular Research, 21: 688-695.

27. Hart G (1994). Cellular electrophysiology in cardiac hypertrophy and failure. Cardiovascular Research, 28: 933-946.

28. Selye H, Bajusz E, Grasso S \& Mendell P (1960). Simple techniques for the surgical occlusion of coronary vessels in the rat. Angiology, 1: 398-407.

29. Hamill OP, Marty A, Neher E, Sakmann B \& Sigworth FJ (1981). Improved patch-clamp techniques for high resolution current recording from cells and cell-free membrane patches. Pflügers Archiv, 391: 85-100.

30. Huang B, Qin D, Deng L, Boutjdir M \& El-Sherif N (2000). Reexpression of T-type $\mathrm{Ca}^{2+}$ channel gene and current in postinfarction remodeled rat left ventricle. Cardiovascular Research, 46: 442449.

31. Lowry CM, Rosebrough NJ, Farr AL \& Randall RJ (1951). Protein measurement with the Folin phenol reagent. Journal of Biological Chemistry, 193: 265-272.

32. Scatchard G (1949). The attraction of proteins for small molecules and ions. Annals of the New York Academy of Sciences, 51: 660672. 
33. Anand IS, Liu D, Chugh SS, Prahash AJC, Gupta S, John R, Popescu F \& Chandrashekhar $Y$ (1997). Isolated myocyte contractile function is normal in postinfarct remodeled rat heart with systolic dysfunction. Circulation, 96: 3974-3984.

34. Zarain-Herzberg A, Afzal N, Elimban V \& Dhalla NS (1996). Decreased expression of cardiac sarcoplasmic reticulum $\mathrm{Ca}^{(2+)}$-pump ATPase in congestive heart failure due to myocardial infarction. Molecular and Cellular Biochemistry, 163-164: 285-290.

35. Mukherjee R \& Spinale FG (1998). L-type calcium channel abun- dance and function with cardiac hypertrophy and failure: a review. Journal of Molecular and Cellular Cardiology, 30: 1899-1916.

36. Scamps F, Mayoux E, Charlemagne D \& Vassort G (1990). Calcium current in single cells isolated from normal and hypertrophied rat heart. Effects of ß-adrenergic stimulation. Circulation Research, 67: 199-208.

37. Götze K \& Jakobs KH (1994). Unoccupied ß-adrenoceptor-induced adenyl cyclase stimulation in turkey erythrocyte membranes. European Journal of Pharmacology, 268: 151-158. 